\title{
Prologue: The Modern Enemies
}

7 here were those in Franklin's time who thought virtue and morality fell too easily from his tongue. The apho-

1 risms he made famous in Poor Richard's Almanac frequently advise good conduct. They urge restraint in eating and drinking, caution in choosing friends; and they suggest that a man should select his wife with his eyes wide open and when the deed is done, close them. They also more commonly praise hard work, saving time, frugality. Not content to give such counsel, Franklin lived a life that exemplified the virtues he advocated and then wrote his Autobiograpby telling about his success in practicing what he preached.

Franklin did much more of course. Almost any of his major achievements would have satisfied an ordinary man. He was a successful businessman, retiring from business when he was fortytwo; in retirement he turned his attention to electricity and dazzled the learned of the century with his experiments. While he did such things, and sat in the legislature at the same time, he served his city in various ways, getting its streets paved and lighted and establishing a fire department, a lending library, schools, and a hospital among other useful institutions. He represented his province in Britain and, a little later, his country in Paris. And through it all, he wrote essays, doggerel, letters, reports of great interest and sometimes of distinction. 
A later age celebrated his achievements, admired his virtues, and wrote his biography over and over again. There is no state named after him, but just about every other sort of institution has been-schools, towns, cities, hospitals, colleges, a mint, and many children as well. All the celebration and honor seem just and appropriate given his achievements.

But such a paragon makes many uneasy. Franklin has too many accomplishments, and he has perhaps received too much commendation. This age in particular seems put off by all that has come to him by way of praise. For Franklin's virtues are those not prized in our time, a period of slack, an age that has made leisure an occupation, one that celebrates the liberated spirit - and fleshnot the disciplined mind.

Even in the nineteenth century, a sterner time than our own but also a century much given to moralism not far different from Franklin's, there were skepties or critics fond of mocking the highmindedness of Franklin and his apparently ceaseless efforts to do good. Mark Twain, for example, took him on, though in a lighthearted way. Twain admired technological genius, and that side of Franklin did not draw his disdain. But Franklin's apparent pleasure in work, pursued early and late, his desire to get something done, and his habit of telling the world about his achievements did-and in Twain's sights loomed as large targets.

"The Late Benjamin Franklin," Twain's memoir, begins in a way characteristic of some of his best humor: "This party was one of those persons whom they call Philosophers." It is clear from that point in the sketch that Twain has little use for those bearing such a designation. For Twain explains that Franklin's philosophy was simply a screen for ideas and conduct calculated to make miserable the lives of boys, "boys who might otherwise have been happy." Twain's Franklin acted with "a malevolence which is without parallel in history" - he "would work all day and then sit 
up nights, and let on to be studying algebra by the light of a smoldering fire, so that all other boys might have to do that also, or else have Benjamin Franklin thrown up to them." As if the hard work were not enough, the Franklin of malevolence also led an ascetic life: "He had a fashion of living wholly on bread and water, and studying astronomy at mealtimes-a thing which has brought affliction to millions of boys since, whose fathers had read Franklin's pernicious biography." Asceticism extended to early rising in the morning, with a boy "hounded to death and robbed of his natural rest because Franklin said once in one of his inspired flights of malignity - Early to bed and early to rise / Makes a man healthy and wealthy and wise.' "The cost to Twain of his parents' experiments on him with this maxim were, he reported, "my present state of general debility, indigence, and mental aberration." Forced to rise before nine o'clock in the morning, he experienced "sorrow" so deep as to defy description. Where, he asks, would he be now had his parents "let me take my natural rest." The answer- "Keeping store, no doubt, and respected by all." 1

This final line suggests several meanings, and Twain's ostensible complaints turn upon themselves. Left to his own devices, including getting up after nine in the morning, he would have attained respectability. But of course he never really had much use for the conventional middle-class life, and his jabs at Franklin's moralism expressed his convictions about its worth. He announced these conclusions in a light spirit, but they reflected the way he felt. The Benjamin Franklin who advocated a regular life, which in its own way was intended to make a man out of a boy"respected by all"-was not for him.

Twain's demolition of the virtues Franklin advocated depended upon an ironic appreciation of what might happen if Franklin's life was not taken as a model. There is a sense of the grotesque in Twain's little sketch, for all its apparent simplicity and indirect- 
ness. Such tactics have not served others critical of Franklin in the modern period.

D. H. Lawrence's essay in Classic Studies in American Literature uses a direct attack. ${ }^{2}$ Lawrence presents Franklin as a "snuffcoloured little man," a bourgeois, self-satisfied man and a threat to the imagination and the spirit. Lawrence seems to have read only Franklin's Autobiograpby and not to have understood that deceptive book. He begins by proclaiming that Franklin believed in the perfectability of man, an erroneous assumption about Franklin that is followed by many others. Clearly what Lawrence despised most in Franklin was the order he represented and exemplified. Franklin, he writes, was good at setting up barbed wire fences, within which "he trotted ... like a grey nag in a paddock." The worst of it was that Franklin wanted a barbed wire fence around everyone, and he wanted everyone to emulate the "pattern" American, a peculiar creature recognizable in his materialism, conventional behavior, and complacency.

The essay Lawrence wrote about Franklin does not really argue a thesis about the great man, the snuff-colored automaton, the enemy of man's mysterious depths. Rather it erupts with anger and violence and makes its point through its explosiveness. There is no joy in Lawrence's demolition of Franklin, no happiness, and his essay's errors and misunderstandings are not really important. What is important is the expression of Lawrence's animus against both Franklin and America as enemies of Europe.

Franklin, Lawrence wrote, "knew that the breaking of the old world was a long process. In the depths of his own unconsciousness he hated England, he hated Europe, he hated the whole corpus of the European being. He wanted to be American." And what was an American, besides an enemy of Europe and the unfettered spirit? Lawrence's America was materialistic and repressive, "tangled in her own barbed wire, and mastered by her own machines. 
Absolutely got down by her own barbed wire of shall-nots, and shut up fast in her own 'productive' machines of squirrels running in millions of cages. It is just a farce." Franklin more than personified all of this. As far as Lawrence was concerned, he had helped produce it.

Franklin's eighteenth-century enemies would not have recognized either Twain's or Lawrence's portraits. To be sure, they shared some of Twain's distaste for Franklin's advocacy of the virtues we have come to associate with the Protestant ethic, Max Weber's term for work, striving, frugality, and asceticism. But most of these enemies, especially in America, believed Franklin lived rather well; and after all, he had retired from the printer's shop when he was only forty-two years of age.

What really called into being Franklin's enemies in his own day was the danger he embodied. To his enemies he was a threatening man-to some a democrat and an egalitarian in an aristocratic age, to others an advocate of change when stability was needed, and finally a libertine given to a dissolute life when self-control and severe morality were required. He was, for these men, anything but the tight little defender of the middle-class world evoked by Twain and Lawrence.

If Franklin could be summoned from his grave, he would surely find the differences in these perceptions interesting, though perhaps he would offer a joke about them. While he was alive, however, he rarely joked about these men-his enemies demanded that he take them seriously. The record shows that he did. 
